\title{
Przyjemność oglądania, czyli filmowe konteksty lektur
}

\section{The pleasure of watching, or the film contexts of reading}

\author{
Elżbieta Kotarba \\ Zespół Szkół - Małopolska Szkoła Gościnności \\ w Myślenicach \\ ORCID: 0000-0002-9747-8443
}

\begin{abstract}
The series of lessons related to Lalka by B. Prus (1890) and the film Jobs by J.M. Stern (2013) showed that the film can deepen the understanding of the characters, as well as the mechanisms of the world presented in the literature and film watched by the students. The juxtaposition of Wokulski and Jobs in the students' mind underlined the nobility of the first one and market mechanism of contemporary corporation of Jobs. The resulting cognitive amalgam revealed the timeliness of the novel: the rapacity of economic processes, social divisions and the human need for love.
\end{abstract}

Key words: film, school reading, pleasure, mental space

Streszczenie: Z lekcji wiążących tematycznie Lalkę B. Prusa (1890) i film Jobs J.M. Sterna (2013) wynikło, że film może pogłębić rozumienie bohaterów, a także mechanizmów świata przedstawionego w lekturze, filmie i otaczającego uczniów. Zestawienie w przestrzeniach mentalnych uczniów Wokulskiego i Jobsa podkreśliło szlachetność pierwszego i rynkowe mechanizmy współczesnych korporacji. Powstały z zestawienia amalgamat kognitywny ujawnił aktualność powieści: drapieżność procesów ekonomicznych, podziały społeczne i ludzką potrzebę miłości.

Słowa kluczowe: film, lektura, przyjemność, przestrzeń mentalna

\section{Film na lekcjach}

Istnieją dwie główne możliwości wykorzystywania filmów na zajęciach języka polskiego. Pierwsza z nich to traktowanie obrazu filmowego jako kontekstu dla problematyki dzieła literackiego. W tym wypadku ogląda się ekranizacje bądź adaptacje, aby wspomóc omawianie lektur. W takim ujęciu sztuka filmowa odzwierciedla omawiane zagadnienia, dopowiada, poszerza, stanowi kontekst dla epoki czy też treści omawianego utworu literackiego. Jest to bardzo popularny model edukacji w szkolnej praktyce. 
Jego zaletą jest wskazanie różnic pomiędzy filmem a książką czy też omówienie wszelkich innowacji, jakie pojawiły się w ujęciu filmowym.

Druga koncepcja polega na tym, aby uczniowie oglądali film, który nie jest adaptacją ani ekranizacją lektury. W takim wypadku obraz filmowy staje się dla nich autonomicznym dziełem:

Oba te aspekty w praktyce analityczno-interpretacyjno-wartościującej wzajemnie się dopełniają, jakkolwiek warto przyjrzeć się każdemu z osobna, zarówno w kontekście projektowania scenariusza zajęć, jak i w żywych rozmowach o filmie z młodymi ludźmi (Bobiński 2016, 147).

Z punktu widzenia szkolnej dydaktyki łączenie lektury z filmem niebędącym jej adaptacją bądź ekranizacją jest wymagające, jeśli chodzi o kompetencje nauczyciela, ale też bardziej interesujące zarówno dla uczniów, jak i dla niego. To nauczyciel najlepiej zna swoich wychowanków i wie, co ich zainteresuje. Ważny w tym kontekście jest wybór odpowiedniego tytułu, który warto z uczniami obejrzeć i omówić:

Wybór ten nie jest łatwy i powinien być uzależniony od kilku czynników: musi być dostosowany do konkretnej grupy uczniów (ich wieku, możliwości percepcyjnych, doświadczeń w zakresie odbioru określonych filmów, zainteresowań), umożliwiać realizację założonych celów edukacyjnych, wreszcie wybrany film powinien dawać szansę łączenia celów edukacyjnych z wychowawczymi (Gołębiowska i in. 2013).

Szukając odpowiedzi na pytanie, jakie filmy oglądać z uczniami, warto zapoznać się z propozycjami przedstawionymi przez polonistycznych dydaktyków (zob. Bobiński 2011, 2016; Ciszewska 2016; Fatyga 2010; Fiołek-Lubczyńska 2004; Gruszczyk 2015; Konieczna 2011; Lubelski 2014; Marzec 1996; Regiewicz 2006; Ślósarz 2001, 2013; Szczepańska 2011). Wielu z nich zaproponowało ciekawe rozwiązania dydaktyczne w zakresie lekcyjnej pracy z obrazem filmowym niebędącym adaptacją danego utworu. Lista proponowanych filmów jest obszerna ${ }^{1}$. Trzeba zaznaczyć, że autorzy podręczników szkolnych także proponują rozwiązania dydaktyczne polegające na łączeniu danego tematu z filmem, który może stanowić kontekst dla danego tematu czy też epoki².

Celem artykułu jest przedstawienie możliwości wprowadzania różnych form obecności filmu na lekcjach języka polskiego, zwłaszcza filmu

\footnotetext{
1 Przykładowe filmy: Amadeusz, reż. Miloš Forman (USA 1984 - epoka oświecenia); Całkowite zaćmienie, reż. Agnieszka Holland (Belgia, Francja, Wielka Brytania, Włochy 1995 - epoka modernizmu); Dług, reż. Krzysztof Krauze (Polska 1999 - do Zbrodni i kary F. Dostojewskiego); Dzień świra, reż. Marek Koterski (Polska 2002 - do Wesela S. Wyspiańskiego); Imię róży, reż. Jean-Jacques Annaud (Francja-Włochy-RFN 1986 - epoka średniowiecza); Jej wysokość Afrodyta, reż. Woody Allen (USA 1995 - do Króla Edypa Sofoklesa); Joanna d'Arc, reż. Luc Besson (Francja 1999 - do Pieśni o Rolandzie); Komornik, reż. Feliks Falk (Polska 2005 - do Miłosierdzia gminy M. Konopnickiej); Obsługiwałem angielskiego króla, reż. Jiří Menzel (Czechy-Słowacja 2006 - do Przedwiośnia S. Żeromskiego); Obywatel Kane, reż. Orson Welles (USA 1941 - do Granicy Z. Nałkowskiej); Piknik pod Wiszaca Skała, reż. Peter Weir (Australia 1975 - epoka romantyzmu); Pokój syna, reż. Nanni Moretti (Włochy 2001 - do Trenów J. Kochanowskiego); Pret-à-porter, reż. Robert Altman (USA 1994 - do Ferdydurke W. Gombrowicza); Siódma pieczęć, reż. Ingmar Bergman (Szwecja 1957 - epoka średniowiecza); Tron we krwi, reż. Akira Kurosawa (Japonia 2006 - do Makbeta W. Szekspira).

2 Proponowane filmy: Forrest Gump, reż. Robert Zemeckis (USA 1994 - jako kontekst do Kandyda Woltera); Amadeusz, reż. Miloš Forman (USA 2010), Misja Barry Lyndon, reż. Stanley Kubrick (USA,
} 
oglądanego dla przyjemności, niebędącego adaptacją bądź ekranizacją lektury. Wymaga to od prowadzącego zajęcia nauczyciela nowego sposobu interpretacji filmu, np. wdrożenia teorii amalgamatów kognitywnych.

\section{Teoria amalgamatów kognitywnych}

Istnieje kilka wyznaczników atrakcyjności filmu: intrygująca fabuła, bliskie odbiorcy problemy, rozmach realizacyjny (dobór aktorów, scenografia, muzyka). Jednak najważniejszym z czynników jest jego aktualność, ponadczasowość oraz uniwersalizm przesłania. Obrazy filmowe, które nie stanowią bezpośredniego przełożenia literatury na ekran, zmuszają młodego widza do określonych procesów myślowych i analitycznych. Uczniowie muszą się zastanowić, które z wątków filmowych można wybrać i wykorzystać do porównania lektury i filmowego kontekstu. Teoria amalgamatów kognitywnych pozwala na przekład intersemiotyczny i nowe odczytanie motywów. Dzięki niej dochodzi również do mechanizmów psychologicznych, które wpływają na rozwój osobowy człowieka. W trakcie oglądania filmu nastolatkowie identyfikują się z bohaterami, co sprawia, że towarzyszą im uczucia, które wynikają z pracy wyobraźni zaangażowanej w zrozumienie narracji:

Mechanizm stapiania przestrzeni mentalnych, inaczej zwany „amalgamacją kognitywną" lub «teorią integracji pojęciowej», w moim przekonaniu odpowiada za jeden z podstawowych aspektów w interpretowaniu filmu: mechanizm zaangażowania emocjonalnego w oglądany spektakl, zwany „identyfikacją”, „utożsamieniem”, „wczuwaniem się" (Skowronek 2013, 20).

Filmy oglądane dla przyjemności często nie nawiązują bezpośrednio do analizowanych na lekcji tekstów. Jednak ich obejrzenie pozwala uczniom na proces identyfikacji, co $\mathrm{w}$ konsekwencji powoduje amalgamowanie wybranych motywów dzieła filmowego i literackiego. Współczesny dostęp do mediów, popularna oraz szeroko dostępna kultura przyjemności z pewnością wpływają na sposób postrzegania świata przez nastolatków. „Dzieci i młodzież wykorzystują nowe media przede wszystkim do celów rozrywkowych" (Huk 2014, 164), dlatego zadaniem szkoły będzie połączenie treści ambitnych z tekstami kultury, które wydają się bliskie i zrozumiałe dla młodego człowieka. Takie zestawienie nie oznacza, że na lekcjach języka polskiego ogląda się filmy dla samego oglądania. Chodzi o to, aby obraz filmowy był na tyle atrakcyjny, by jego porównanie z lekturą omawianą na lekcji bardziej zaangażowało młodego człowieka, pobudziło go do myślenia, sprawiło, że lekcja stanie się dla niego ciekawa, a poznane historie zaangażują go emocjonalnie i pozwolą na identyfikację z bohaterami.

Wielka Brytania 1975), Szaleństwo króla Jerzego, reż. Nicholas Hytner (Wielka Brytania 1994), Braterstwo wilków, reż. Christophe Gans (Francja 2001) - jako konteksty dla epoki oświecenia. 


\section{Filmowe konteksty Lalki}

Odbiór Lalki zmienia się wraz z upływem czasu. Istnieją zależności pomiędzy nowymi koncepcjami teoretycznoliterackimi a odczytywaniem powieści: badacze literatury odnosili się zarówno do metody hermeneutycznej (Przybyła 1995), jak również do psychoanalizy (Tokarczuk 2001). Nauczyciel polonista stając przed ponad trzydziestoosobową grupą nastolatków, musi zadać sobie podstawowe pytanie: W jaki sposób i za pomocą jakich metod omówić na kilku jednostkach lekcyjnych Lalkę? Kolejne pytanie dotyczy wyboru filmu korespondującego z omawianą lekturą. Jednym $\mathrm{z}$ nich jest Lalka w reżyserii Wojciecha Jerzego Hasa. To film wyprodukowany w 1968 roku. Has przedstawił barwne tło XIX-wiecznej Warszawy. Sam z wykształcenia był malarzem, co niewątpliwie wpłynęło na realizację scenografii filmowej:

W realistycznej powieści Prusa Has dostrzega świat pełen tajemnic i onirycznej realności. Jest świadomy wielu silnych emocji drzemiących w tekście pisarza. Reżyserując Lalkę, wykorzystał taką ekspresję filmową, która oddała zarówno poczucie nadchodzącego końca pewnej epoki, kres barwnego życia arystokracji, jak i głęboki pesymizm bijący z historii (Rożen-Wojciechowska 2007, 117).

Wizja reżysera sytuuje film w kręgu dzieł ponadczasowych (Podsiadło 2014, 44-69; Kosecka, Kubisiowska 1999, 78-87). Jednak jest to obraz będący adaptacją powieści Prusa, stąd ta propozycja w kontekście niniejszego artykułu nie wydaje się adekwatna. Filmowym kontekstem Lalki, niebędącym jej ekranizacją, może być Ziemia obiecana Andrzeja Wajdy:

wydaje się użytecznym kontekstem dla rozważań zarówno o epoce pozytywizmu, jak i Młodej Polski, w istocie zaś może znakomicie pełnić rolę „pośrednika” między obydwoma zjawiskami kulturowo-społecznymi. (...) stanowi zatem pomoc przy rekonstrukcji kontekstu macierzystego dzieł takich jak Lalka czy Ludzie bezdomni, choć przecież nie jest z nimi bezpośrednio związany (Bobiński 2016, 213-214).

Film ten pełni istotną rolę w zrozumieniu lektur szkolnych opisujących rzeczywistość drugiej połowy XIX wieku. Obraz Wajdy należy do arcydzieł polskiej kinematografii. Przyniósł reżyserowi pierwszą nominację do Oscara, a w 2015 roku - w plebiscycie ogłoszonym przez Muzeum Kinematografii w Łodzi - Ziemia obiecana zajęła pierwsze miejsce na liście najlepszych filmów polskich wszech czasów. Jednak ta propozycja może nastręczać młodzieży wiele trudności. Film opowiada o rzeczywistości dla nich odległej, związanej z przeobrażeniami gospodarczymi XIX wieku³, wymaga więc dojrzałości odbiorczej.

${ }^{3}$ Andrzej Wajda zdecydował po 25 latach, że film należy zmontować od nowa: „Przed laty chwalono rytm i impet «Ziemi obiecanej», dziś jednak wydały mi się one niewystarczające; przemontowałem więc film na nowo” (Kino 2000,4). Reżyser dokonał kilku zmian, które w efekcie spowodowały nadanie jego dziełu szybszego rytmu i żywszego pulsu (por. Lubelski 2000, 4-5, 61).

Polonistyka. Innowacje

Numer 12,2020 


\section{Jobs J.M. Sterna}

Można zatem powiązać odczytywanie Lalki z filmem pt. Jobs w reżyserii Joshuy Michaela Sterna (USA 2013)4. Jest to dramat biograficzny przedstawiający życie Steve’a Jobsa - twórcy marki Apple. Główny bohater to postać kontrowersyjna, nietuzinkowa i oryginalna. Był wynalazcą i wizjonerem, świetnie orientował się w prawach i zasadach rynku. W 1976 roku, wraz ze Steve'em Wozniakiem, założył firmę Apple. Po wielu perypetiach osiągnął sukces i stał się twarzą spełniającego się american dream. Z drugiej strony Jobs był postrzegany jako człowiek bardzo wymagający, mało empatyczny, a wręcz brutalny w stosunku do bliskich, zwłaszcza do córki (por. Isaacson 2015; Brennan-Jobs 2019). Reżyser w filmie pominął kilka ważnych wydarzeń z życia bohatera:

Zaczynamy od Jobsa, który wciąga kwas i przybiera chrystusowe pozy w łanach pszenicy. Niecałe dwie godziny (i dwadzieścia lat) później to już inny człowiek. Gdy przegląda się w oczach zapatrzonego w niego jak w obrazek Jonathana Ive’a (główny projektant Apple’a), widzimy, że w międzyczasie dorobił się wiernych wyznawców. Obserwujemy przemianę buszującego-w-zbożu hipisa w boga hipsterów, a jednak sekret tej transformacji pozostaje dla nas niedostępny (Popielecki 2013).

Jobs został przedstawiony jako charyzmatyczny geniusz informatyki. Zrezygnował ze studiów, ponieważ czuł się osaczony i stłamszony przez utarte schematy edukacyjne. Chciał osiągnąć coś więcej niż wykształcenie - takie samo, jak setki tysięcy jego rówieśników. Dlatego wyruszył w podróż, aby znaleźć sens życia. W końcu zrozumiał, że pragnie stworzyć komputer, który znacząco będzie się różnił od dotychczasowego urządzenia. Byłby to komputer osobisty, dostępny dla każdego, a przy tym estetyczny i funkcjonalny. Jego wizji nie rozumieli najbliżsi mu współpracownicy. Tymczasem Jobs wymagał od nich coraz więcej, chciał, aby tworzyli urządzenia, których nikt nigdy nie był w stanie zrobić. Tym samym jego relacje z bliskimi stawały się coraz trudniejsze, był krytykowany, aż wreszcie musiał odejść z firmy, którą sam założył. Jobs jednak nie poddał się, ciężko pracował, tworzył i wierzył w swoją wizję.

Jego biografia jest wciąż interesująca, a równocześnie inspirująca dla współczesnej młodzieży.

\section{Zestawienie przestrzeni mentalnych}

Steve Jobs to postać znacząco różniąca się od głównego bohatera Lalki, zwłaszcza jeśli chodzi o relacje z ludźmi. Istnieją jednak również pewne podobieństwa. To, co ich łączy, to realizowanie własnych pasji, chęć poprawienia poziomu życia ludzkości oraz pragnienie przyczyniania się do rozwoju cywilizacji, a przy okazji bogacenie się i przedsiębiorczość. Na tym głównie polegałoby uaktualnienie odczytania Lalki w zestawieniu z obrazem Sterna. Aby uczniowie mogli dostrzec podobieństwa i różnice między

4 Scenariusz: Matt Whiteley; obsada: Ashton Kutcher (Steve Jobs), Josh Gad (Steve Wozniak), Dermot Mulroney (Mike Markkula). 
bohaterami - Wokulskim i Jobsem - warto podać im do wypełnienia karty pracy $^{5}$. Po ich uzupełnieniu wyłoni się uporządkowane zestawienie cech wspólnych oraz różnic pomiędzy bohaterami ${ }^{6}$. Projekt ten miał na celu zestawienie przestrzeni mentalnych (Libura 2007). Rzeczywiste wypowiedzi uczniów przerosły oczekiwania. Wynika z nich, że dostrzegają zbieżności w biografii obu bohaterów. Zwrócili uwagę na takie sceny, jak: rezygnacja ze szkoły (Jobs z powodu niedostosowania/znudzenia/niezadowolenia, Wokulski z powodu udziału w powstaniu styczniowym), praca nad wynalazkiem (Jobs w garażu, Wokulski w winiarni Hopffera), lekceważenie otoczenia (zwłaszcza moment, gdy Jobs przedstawił projekt Macintosha; scena wychodzenia Wokulskiego z piwnicy). Uczniowie zestawili sekwencje filmowe z Lalkq, zwracając uwagę na analogię między biografią Jobsa i Wokulskiego. Wskazywali na różnice wynikające z uwarunkowań społeczno-ekonomicznych, co wiąże się z pogłębieniem znajomości treści lektury.

Porównując te dzieła, warto zwrócić uwagę szczególnie na trzy aspekty: ekonomiczny, społeczny oraz psychologiczny.

\section{a) aspekt ekonomiczny}

Kiedy miałem 23 lata byłem wart ponad milion dolarów, (...) a kiedy miałem 25 lat było to już ponad 100 milionów dolarów. Ale to się nie liczyło, ponieważ nigdy nie robiłem tego dla pieniędzy (S. Jobs) ${ }^{7}$

No dobrze, ale gdyby nie ona, czy miałbym dziś majątek?... Kto wie, co się stanie ze mną i z tymi pieniędzmi bez niej? (S. Wokulski)

(Prus 2004, 77)

Nasz świat się komercjalizuje. Ekonomia wkroczyła w niemal każdą dziedzinę ludzkiego życia. Pieniądze stają się wyznacznikiem wartości człowieka, a niekiedy sensem i celem życia. Okazuje się, że nie jest to rys charakterystyczny tylko naszych czasów. Tak było już ponad sto lat wcześniej, o czym traktuje Lalka Prusa (Bachórz 1991, 2019). Główny bohater jest wyśmienitym przedsiębiorcą i strategiem finansowym, a mimo to

\footnotetext{
5 Por. Aneks.

6 Oto przykładowe wypowiedzi uczniów: Podobieństwa: „bohaterowie rzucili szkołę”; „fascynowali się nauką i wiele dla niej poświęcili”; „mieli przyjaciela - naukowca”; „potrzebowali pieniędzy, aby zrealizować swoje idee”; „potrafili zarabiać pieniądze”; „założyli firmy”; „współpracowali z ludźmi innej narodowości”; „byli narażeni na krytykę”; „inni plotkowali na ich temat”; „byli indywidualistami”; „wyalienowani ze środowiska”; „egocentryczni”; „bez skrupułów zwalniali swoich pracowników”. Różnice: Wokulski - „pomagał biednym, był filantropem”; „realizował pozytywistyczne idee (praca u podstaw, praca organiczna, asymilacja Żydów, emancypacja kobiet)”; „żył w społeczeństwie podzielonym na klasy społeczne, co go ograniczało jako wizjonera”; „kierował się w życiu miłością do jedynej kobiety i wszystko robił dla niej”; „dla niego ważniejsza była miłość niż pieniądze”; „żył w 2 poł. XIX w (rozbiory, powstanie)”. Jobs - „nie zajmował się biednymi”; „realizował własne wizje i idee”; „żył w społeczeństwie wolnym, gdzie nie było podziałów ze względu na pochodzenie”; „miłość do kobiety nie była dla niego najważniejsza”; „za wszelką cenę chciał osiągnąć sukces”; „żył w wolnym kraju w XX w, gdzie był tzw. wolny rynek".

7 Wszystkie wypowiedzi Steve'a Jobsa pochodzą z artykułu: Steve Jobs - 13 inspirujących myśli, http://www.milosctopasja.com/artykuly/pelny/672/nie-mozesz-polaczyc-kropek-patrzac-do-przodu (dostęp: 23.07.2019).
} 
ponosi klęskę, bowiem pieniądze rządziły nie tylko gospodarką, ale również innymi dziedzinami życia:

Genialny Bolesław Prus fenomenalnie pokazał zaawansowane studium procesu, w którym myślenie ekonomiczne pustoszy bezpowrotnie coraz większe obszary moralności, metafizyki, estetyki, idei. Prus wie zarazem, że możliwość pomnażania pieniędzy przez każdego to potężny instrument uwalniania człowieka z podległości wobec natury lub stosunków społecznych (Koziołek 2016, 30).

Pozornie historia Jobsa w zestawieniu z Wokulskim jest nieco inna. Obaj osiągają sukces finansowy i awans społeczny. Jednak w filmie główny bohater podejmuje decyzje na podstawie analizy kosztów, a jego wybory wynikają z przewidywanych korzyści. Nie zważa na straty moralne - w świecie kapitalizmu i liberalizmu wszystko jest dozwolone. Obowiązki moralne, jak opieka nad własnym dzieckiem, przyjaźń czy miłość, odsuwa na dalszy plan. Dla niego najważniejsza jest marka Apple i realizowanie swoich projektów. Wokulski tymczasem podporządkowuje swoje działania, a w konsekwencji własne życie, wybrance serca. Chce ją zdobyć przez pomnażanie własnego majątku. Wie, że w jej postrzeganiu świata najważniejsze są dobra materialne. Dlatego gromadzi pieniądze:

Ile zatem kosztuje Izabela? Nie oburzajmy się pochopnie na to obcesowe pytanie. Imię powieściowej bohaterki odsyła bowiem nie tylko do osoby, ale także do przedmiotu matrymonialnej transakcji, prestiżu społecznego, obiektu erotycznego, miejsca w strukturze społecznej i wielu innych dóbr w najwyższym stopniu ekonomicznych. Bez względu na to, jaka treść została w powieści oznaczona tym imieniem, zawsze dotyka jej ręka rynku (Koziołek 2016, 31).

Jednak uczucia nigdy nie idą w parze z ekonomią. Fakt, że pieniądze niezależnie od czasów decydowały o ludzkim życiu, jest niewątpliwie ważnym aspektem odczytywania lektury. Zwrócenie uwagi na aspekt ekonomiczno-finansowy w zestawieniu ze współczesnym bohaterem - idolem młodych ludzi - czynią problematykę Lalki bardziej ciekawą.

Z ankiet przeprowadzonych na zajęciach dydaktycznych widać, że uczniowie dostrzegli analogie pomiędzy bohaterami i byli w stanie je zinterpretować. Świadczą o tym odpowiedzi na pierwsze pytanie: Opisz scene filmowa, która według ciebie można odnieść do „Lalki”. Uzasadnij swój sq̨d. Oto niektóre odpowiedzi:

Scena, którą moim zdaniem można odnieść do «Lalki», pokazuje Jobsa i jego przyjaciela, którzy po raz pierwszy pokazywali swoją nową płytę do komputera. Ludzie podchodzili do niej sceptycznie, negatywnie, a nawet wychodzili z sali. Stosunek ludzi do wynalazku Jobsa i jego przyjaciela można odnieść do stosunku ludzi do Wokulskiego, próbującego wynaleźć perpetum mobile. Ludzie również bardzo negatywnie oceniali Wokulskiego i jego wynalazek, nie postrzegali go na poważnie. (Natalia O.)

Najbardziej lalkopodobna scena, w której podobieństwo między Jobsem a Wokulskim jest najbardziej wyraziste, to scena w której Steve po odrzuceniu go 
z projektu «Cisa» zabrał się do stworzenia nowej drużyny pracującej nad projektem Macintosh. Analogicznie Wokulski na spotkaniu u Księcia, gdy jego idea poruszyła nawet zatwardziałych mieszczan. (Daniel D.)

Scena ta opisuje, kiedy Steve w pierwszej, przedstawionej nam, jego pracy, mówi do swojego szefa, ze chce stworzyć kolorową grę, a ten odpowiada, że jest to niemożliwe. Mówi mu też, że niczego nie osiągnie w swoim życiu. Jednak Jobs dzięki swoim umiejętnościom, pomysłom stworzył coś niezwykłego i wszyscy zaczęli go szanować. Tak samo było z Wokulskim. Na początku wszyscy uważali, że ma tylko pieniądze odziedziczone po Małgorzacie, a sam niczego nie osiągnie lecz później, gdy pomnożył swój majątek ludzie zaczęli go szanować. (Jakub D.)

Większość wypowiedzi nastolatków koncentrowała się na pracy bohaterów oraz ich relacji z otoczeniem. Okazuje się, że ekonomia rządzi bohaterami obu tekstów kultury. Jednak nie dla pieniędzy pracują i nie dla nich stają się przedsiębiorcami. W obu przypadkach pieniądze są tylko skutkiem ubocznym ich fascynacji i pasji. Dla Wokulskiego pasją była Izabela, a dla Jobsa komputer. Nie zmienia to jednak faktu, że aspekt ekonomiczny wpłynął na kształt życia obu bohaterów.

\section{b) aspekt psychologiczny}

Ci, którzy są wystarczająco szaleni, by myśleć, że są w stanie zmienić świat, są tymi, którzy go zmieniają. (S. Jobs)

A ja czy dzisiaj nie mam idei, dla której pracuję przeszło rok? (S. Wokulski)

(Prus 2004, 159)

Drugi aspekt to wspólna cecha obu bohaterów, jaką jest dążenie do celu. Zarówno w książce, jak i w filmie widać, że obaj pragną realizować swoje marzenia i pasje. Jako wyjątkowi ludzie wyróżniają się na tle społecznym, patrzą na świat inaczej, dostrzegają potrzeby ludzkości. Chcą zmieniać rzeczywistość, rozwijać swoje talenty oraz zainteresowania.

Widać to w scenach, kiedy Steve Jobs założył własną firmę i powoli, konsekwentnie zdobywał uznanie wśród ludzi oraz pomnażał majątek. Potem jednak pojawiły się problemy ze współpracownikami oraz niechęć i brak zrozumienia ze strony innych. Kilka scen z filmu zasługuje na uwagę. W jednej z nich Jobs - mimo niepowodzeń - pracuje dniami i nocami w garażu adopcyjnych rodziców, tworząc udoskonalony komputer ${ }^{8}$. Mike Markkula mówi: „Dokonywał niemożliwego, nawet gdy pracował w garażu”. Istotne są również rozmowy z pracownikami na temat własnych oczekiwań stworzenia domowego komputera ${ }^{9}$ oraz scena, kiedy bohater prezentuje swoje pomysły, a jednak nie zyskuje aprobaty potencjalnych sponsorów ${ }^{10}$. Te obrazy można zestawić z biografią Wokulskiego, który pomimo niechęci otoczenia realizował swoje cele, rozwijał talent przedsiębiorcy i naukowca. W obu

Jobs [film], 22'-24'. 
przypadkach można wskazać na metaforę piwnicy. Praca Jobsa w garażu oraz symboliczna scena wydostawania się Wokulskiego z piwnicy wskazują na ich samozaparcie i upór. Zarówno Wokulski, jak i Jobs, za wszelką cenę pragnęli zrealizować swoje marzenia i ambicje naukowe. Jobs mówi:

Zaczynamy od kłopotu, który trzeba rozwiązać. Bez zapału nie będziecie mieć siły, żeby doprowadzić to do końca (...). Stoimy przed szansą zbudowania czegoś rewolucyjnego. Życie pozwala spełnić część swoich marzeń. Teraz przyszła kolej na to marzenie (Jobs [film] 2013, 1h11'-1h13').

Takie zestawienie sekwencji filmowych $\mathrm{z}$ fragmentami lektury pozwala zauważyć miejsca wspólne obu dzieł: samotność i pasję bohaterów oraz wytrwałe dążenie do osiągnięcia celów:

Czas wolny od nauki poświęcał Stach na próby z balonami. Wziął dużą butlę i w niej za pomocą witriolu preparował jakiś gaz (...) i napełniał nim balon nieduży wprawdzie, ale przygotowany bardzo sztucznie. Była pod nim maszynka z wiatraczkiem... No i latało to pod sufitem, dopóki nie zepsuło się przez uderzenie o ścianę. W takim razie Stach znowu łatał swój balon, naprawiał maszynkę, napełniał butlę rozmaitymi paskudztwami i znowu próbował, bez końca. (...) za pomocą balonu chciał «wydobyć się» ze swej marnej pozycji (Prus 2004, 295).

Równocześnie można zauważyć w obu tekstach kultury te same cechy bohaterów: impulsywność, skrytość i oschłość. Podobnie jak Jobs:

Wokulski prawie nigdy nie okazuje uczuć (...). Zamiast tego działa. (...) Może dlatego charakterystyczne są dla niego nagłe zmiany decyzji, nastrojów i percepcji, chłód i gorączka. (...) Ma potężną potrzebę samodoskonalenia się (słynne wydobywanie się z piwnicy bez schodów (...) symbol, który przylgnie już do postaci Wokulskiego, stając się źródłem znaczeń społecznych). Jest skryty, nawet dla najbliższych (Tokarczuk 2001, 35).

Ciekawe mogą być przyczyny takiego stanu rzeczy. Obu bohaterów pcha do przodu jakaś wewnętrzna siła, która kieruje ich w stronę działania, odkrywania i zmieniania świata na lepsze. Być może w obu przypadkach źródłem samodoskonalenia się i udowadniania innym swojej wartości jest brak szczęśliwego dzieciństwa. Wokulski „rodzi się w tej powieści jako homunkulus - od razu gotowy" (Tokarczuk 2001, 35). Obaj również stanowią przykład bohatera, którego można nazwać self made man'em.

\section{c) aspekt społeczny}

Nie pozwólcie, żeby hałas cudzych opinii zagłuszył wasz własny wewnętrzny głos. (S. Jobs)

Najgorszą samotnością nie jest ta, która otacza człowieka, ale ta pustka w nim samym. (S. Wokulski)

(Prus 2004, 31)

Dążenie do własnych celów mimo braku akceptacji pociąga za sobą konsekwencje, takie jak brak zrozumienia przez innych czy wręcz odrzucenie. 
Bohaterowie obu dzieł są indywidualistami, czują się osamotnieni. Widać to wyraźnie w filmowych scenach, kiedy Jobs sam, boso, zamyślony przechadza się ulicami bądź korytarzami. Jego pogłębiająca się izolacja osiągnie apogeum w scenie rozmowy z przyjacielem Wozniakiem, który zdecydował się odejść ze wspólnie założonej firmy. Zarzucił on Jobsowi brak empatii oraz porzucenie wartości, które kiedyś im przyświecały. Mówi:

Idę stąd, Steve. (...) Odchodzę z Apple. Na zawsze. (...) Nie pamiętam, kiedy ostatnio rozmawialiśmy. Przypominam sobie, jak byliśmy młodzi, przesiadywaliśmy w garażu twojego ojca (...). Tobie już nie chodzi o ludzi. Liczy się produkt. A co gorsza... liczysz się tylko ty. (...) Musisz być strasznie samotny. (...) Nie wiem, jak ty widzisz swoją przyszłość, ale ja czarno ją widzę. Nie mam zamiaru na to patrzeć. To było niesamowite doświadczenie. I żebyś pamiętał... Uwielbiam to, co stworzyliśmy (Jobs [film] 2013, 1h25'-1h28').

Izolacja Jobsa jest spowodowana głównie jego trudnym charakterem. Ludzie odwracają się od niego, bo jest zbyt wymagający, wyniosły i agresywny. Sam Jobs nie przeżywa tak bardzo odrzucenia przez środowisko, w myśl zasady, że trzeba mieć odwagę, aby kierować się własnym sercem i intuicja. Samotność głównego bohatera Lalki widać bardzo wyraźnie od pierwszych stron lektury aż do jej końca. Jest to samotność wewnętrzna i zewnętrzna, której przyczyn można szukać w wielu źródłach. Bohater ma osobowość neurotyczną (Tomkowski 1993), co wpływa na jego osobiste relacje z ludźmi. Jednak główną przyczyną wyizolowania jest nieodwzajemniona miłość do panny Izabeli oraz wyraźne podziały społeczne:

Motyle istnieją także w rodzaju ludzkim (...). A ty robaku, nurtuj ziemię i przerabiaj ją na grunt zdolny do siewu. Oni bawią się, ty pracuj; dla nich istnieje wolna przestrzeń i światło, a ty ciesz się jednym tylko przywilejem: zrastania się, jeżeli cię rozdepcze ktoś niezauważony. I tobież to wzdychać do motyla, głupi?... I dziwić się, że ma wstręt do ciebie?... Jakiż łącznik może istnieć między mną i nią?... (Prus 2004, 76-77).

Metafora o motylach i robakach trafnie charakteryzuje obraz polskiego społeczeństwa, a równocześnie podkreśla kontrast między Wokulskim a Izabelą. Odrzucenie jego miłości przez arystokratkę czyni go głęboko nieszczęśliwym, a kolejne próby zdobycia jej uczuć izolują go coraz bardziej w społeczeństwie:

Wokulski sam siebie także spostrzega jako Obcego. Instynktownie szuka «swojego świata», przeczuwa jego istnienie i przeciwstawia go «temu światu». Ma wyobrażenie lepszej rzeczywistości, która istnieje w nieokreślonej przyszłości i która zostanie dopiero ustanowiona dzięki odkryciom naukowym (Tokarczuk 2001, 54).

Podobnie Jobs - nie daje się wciągnąć w porządek tego świata. Ciągle ma przeczucie, że można stworzyć inną, lepszą rzeczywistość. Jego gorączkowe działania przynoszą efekty w postaci założonej firmy oraz korzyści finansowych. Podobnie jest w przypadku Wokulskiego, który po powrocie z wojny w 1878 roku zwierza się Rzeckiemu, że zarobił dużo pieniędzy. 
Mimo to obaj bohaterowie są samotni i czują wewnętrzną pustkę: „najgorszą samotnością nie jest ta, która otacza człowieka, ale ta pustka w nim samym" (Prus 2004, 31) - przyznaje Wokulski. Być może odrzucenie to cena, jaką trzeba zapłacić, aby stać się osobą wielkiego formatu, której „nie wystarcza wypełnienie życia materialnym dobrobytem, (...) która chce nie tylko przetrwać, ale mieć dla swego życia usprawiedliwienie" (Kosecka, Kubisiowska 1999, 81).

Film, podobnie jak książka, pozwala odbiorcy utożsamić się z bohaterem, przeżywać jego problemy, wyciągać wnioski. W produkcji Jobs kłopoty bohatera $\mathrm{z}$ otoczeniem pokazują widzom, że jest to zjawisko występujące w życiu wielu ludzi, nawet najbardziej znanych. Na aspekt psychologiczno-terapeutyczny obrazu Sterna zwracali uwagę również sami uczniowie, o czym świadczą ich odpowiedzi na drugie pytanie: Czy dzięki zestawieniu "Lalki" z filmem "Jobs", lektura bardziej Cię zainteresowała, zainspirowała do własnych przemyśleń? Uzasadnij swój sąd. Na to pytanie $90 \%$ respondentów udzieliło odpowiedzi twierdzącej. Oto niektóre uzasadnienia:

Tak, dzięki filmowi, «Lalka» stała się dla mnie bardziej interesująca i zainspirowała mnie do własnych przemyśleń dotyczących moich planów i ich realizacji, ponieważ pokazuje, że nie warto się poddawać i nie przejmować się tym, co mówią ludzie. (Natalia O.)

Uważam, że dzięki zestawieniu lektury z wybranym filmem zainteresowałam się bardziej «Lalką». Wcześniej nie przyszłoby mi na myśl, że tak dwie odległe w czasie kreacje można ze sobą porównać i zauważyć między nimi podobieństwa. Postać Jobsa sprawiła, że spojrzałam na Wokulskiego z innego punktu widzenia i powróciłam do lektury. (Aleksandra Dan.)

Tak (...) sądzę, że losy głównego bohatera filmu Steva jak najbardziej można porównać z losami Wokulskiego. Obie postacie przez całe życie musiały zmagać się z przeciwnościami i trudnościami. (Aleksandra Dąb.)

Dzięki temu zestawieniu lektura mnie bardziej zainteresowała, ponieważ daje to ciekawsze spojrzenie na intelektualistów na przestrzeni lat. Film skłania do refleksji nad możliwością Wokulskiego, człowiek zastanawia się i dochodzi do wniosku, że Wokulskiemu mogłoby się udać w późniejszych czasach bo ludzie byliby dla niego mniej sceptycznie nastawieni co wspierałoby go moralnie w dążeniu do celu. (Daniel D.)

Po obejrzeniu filmu i przeczytaniu książki zostałem zainspirowany do przemyślenia na temat dwóch dróg: oddaniu się miłości i pasji życiowej. Wokulski chciał osiągnąć szczęście przez zdobycie miłości i uznania Izabeli co niestety mu się nie udało w przeciwieństwie do Jobsa który obrał za cel realizację swojej życiowej pasji i za wszelką cenę doprowadzić swoją firmę na szczyt. (Jakub Z.)

Uczniowie zapytani, do jakich przemyśleń zainspirował ich film, zwrócili uwagę na podobieństwo głównych bohaterów w zakresie zmagania się z przeciwnościami losu oraz dążenia do wybranego celu. Młodzi ludzie wskazywali, iż film pobudził ich do refleksji nad własnym życiem. Pokazał, że nigdy nie należy się poddawać. 
Tak więc dzięki filmowi Sterna rozumienie powieści Prusa zostało pogłębione. Zestawienie $\mathrm{w}$ przestrzeniach mentalnych uczniów Wokulskiego i Jobsa podkreśliło szlachetne cechy pierwszego $\mathrm{z}$ nich oraz rynkowe mechanizmy działania współczesnych korporacji. Powstały w rezultacie zestawienia amalgamat kognitywny ujawnił aktualność powieści Prusa, zwłaszcza odwieczną drapieżność procesów ekonomicznych, niezmienne podziały społeczne oraz ludzką potrzebę miłości.

\section{Bibliografia}

Bachórz Józef, (oprac.), 1991, Bolesław Prus «Lalka», Wrocław.

Bachórz Józef, O pieniądzach i kwestiach ekonomicznych $w$ «Lalce» Bolesława Prusa, https://iterat.ug.edu.pl/pieniadz/0012.htm (dostęp: 18.07.2019).

Bobiński Witold, 2011, Teksty w lustrze ekranu: okołofilmowa strategia kształcenia literacko-kulturowego, Kraków.

Bobiński Witold, 2016, Wykształcić widza. Sztuka ogląania w edukacji polonistycznej, Kraków.

Brennan-Jobs Lisa, 2019, Płotka, Warszawa.

Ciszewska Ewa, Klejsa Konrad, (red), 2016, Od edukacji filmowej do audiowizualnej. Teorie i praktyki, Łódź.

Fatyga Anna, 2010, Literatura i ekran czyli spotkania z filmem na lekcjach języka polskiego, Kraków.

Fiołek-Lubczyńska Bogumiła, 2004, Film, telewizja i komputery w edukacji humanistycznej. O audiowizualnych tekstach kultury, Kraków.

Gołębiowska Dorota, Górecka Danuta, Kanownik Ewa, Kołodziejczak Anna, Mostowska Jadwiga, 2018, Film w edukacji polonistycznej - przy jakich okazjach edukacyjnych po niego sięgać?, „Polski w Praktyce”, nr 22.

Gruszczyk Tomasz, 2015, Czytanie filmu - ogladanie literatury. Propozycje interpretacji do spotkań edukacyjnych, Katowice.

Huk Tomasz, 2014, Pedagogika medialna. Aspekty społeczne, kulturowe i edukacyjne, Kraków-Katowice.

Isaacson Walter, 2011, Steve Jobs, Kraków.

Jobs [film], reż. Joshua Michael Stern, Warszawa: G+J Gruner+Jahr Polska Sp. z o.o. \&Co, 2013, 1 płyta DVD.

Konieczna Ewelina, 2011, Filmowe obrazy szkoły. Pomiędzy ideologia, edukacja a wychowaniem, Kraków-Katowice.

Kosecka Barbara, Kubisiowska Katarzyna, 1999, Lektury na ekranie czyli mały leksykon adaptacji filmowych, Kraków.

Koziołek Ryszard, 2016, Dobrze się myśli literatura, Wołowiec.

Libura Agnieszka, 2007, Amalgamaty kognitywne w sztuce, Kraków.

Lubelski Tadeusz, 2000, Stara i nowa „Ziemia obiecana”. Z Andrzejem Wajda rozmawia Tadeusz Lubelski, „Kino”, nr 9, s. 4-5, 61. 
Marzec Anna, 1996, Ze słowa na obraz. Lektury szkolne na ekranie, Kraków.

Podsiadło Magdalena, 2014, Dalej aktualne. „Lalka” Wojciecha Jerzego Hasa według Bolesława Prusa, w: Lubelski T. (red), Od Mickiewicza do Masłowskiej. Adaptacje filmowe literatury polskiej, Kraków, s. 44-69.

Popielecki Jakub, 2013, Niedaleko pada Kutcher od Jobsa. Recenzja filmu «Jobs» (2013), https://www.filmweb.pl/review/Niedaleko+pada+Kutcher+od+Jobsa-14679 (dostęp: 20.07.2019).

Prus Bolesław, 2004, Lalka, Kraków.

Przybyła Zbigniew, 1995, «Lalka» Bolesława Prusa. Semantyka - kompozycja - konteksty, Rzeszów.

Regiewicz Adam, 2006, Dialog filmu z literatura. Scenariusze lekcji dla liceum i technikum, Gdańsk.

Rożen-Wojciechowska Joanna, 2007, O tym, jak ze słów powstaje obraz. Adaptacja „Lalki” w reżyserii Wojciecha Jerzego Hasa, Warszawa.

Skowronek Bogusław, 2013, Kognitywny model identyfikacji w odbiorze dzieła filmowego, „Dot. Comm”, nr 1-2, s. 19-25.

Steve Jobs - 13 inspirujacych myśli, http://www.milosctopasja.com/artykuly/pelny/672/nie-mozesz-polaczyc-kropek-patrzac-do-przodu (dostęp: 23.07.2019).

Szczepańska Ewa, 2011, Edukacja filmowa w szkole, Poznań.

Ślósarz Anna, 2001, Lektury licealne a kino komercyjne. Aksjologiczny wymiar edukacji filmowej, Kraków.

Ślósarz Anna, 2013, Ideologiczne matryce. Lektury a ich konteksty. Postkomunistyczna Polska - postkolonialna Australia, Kraków.

Tokarczuk Olga, 2001, «Lalka» i perła, Kraków.

Tomkowski Jan, 1993, Neurotyczni bohaterowie powieści Prusa, w: Tomkowski J., Mój pozytywizm, Warszawa.

Tomkowski Jan, 1993, Spór o «Lalkę», w: Łukasiewicz J. (red), Z badań nad polska tradycja literacka, Wrocław.

\section{O Autorce}

Elżbieta Kotarba - doktor nauk humanistycznych. Napisała rozprawę na temat: Kształtowanie postaw i systemu wartości uczniów w lekcyjnych rozmowach o wierszach Krzysztofa Kamila Baczyńskiego. Próba odczytania aksjologicznego wymiaru wybranych utworów. Nauczycielka języka polskiego w Zespole Szkół - Małopolskiej Szkole Gościnności w Myślenicach. 


\section{Aneks:}

KARTA PRACY:

\begin{tabular}{|l|l|l|}
\hline przykładowe kryteria: & Wokulski: & Jobs: \\
\hline PODOBIENSTWA: & & \\
stosunek bohaterów do np.: & & \\
• szkoły & & \\
- nauki pracowników & & \\
- pieniędzy & \\
- wspólne cechy cha- & & \\
rakteru & & \\
RÓżNICE: & \\
stosunek bohaterów do np.: & & \\
• biednych & \\
- kobiet & \\
• uwarunkowania spo- & & \\
łeczne i polityczne & & \\
• różne cechy charak- & & \\
teru & & \\
\hline
\end{tabular}

